\title{
Noise Komunikasi dalam Penanganan Wabah COVID-19 (Studi Deskriptif-Kualitatif Penanganan Covid-19 di NTB)
}

\author{
Muhammad Jamiluddin Nur, ${ }^{1}$ Pundra Rengga Andhita, ${ }^{2}$ Baiq Vira Safitri ${ }^{3}$ \\ 1,3Universitas Mataram, Mataram, Indonesia, jamilnur@unram.ac.id; b.vira.safitri@gmail.com \\ 2Universitas Muhammadiyah Surakarta, Surakarta, Indonesia, pra702@ums.ac.id \\ Communication Noise in Combating Covid-19 Pandemic \\ (Qualitative-Descriptive Research on Combating Covid-19 in NTB)
}

\begin{abstract}
This study aims to describe the communication noise that occurs in the process of handling the Covid19 outbreak in NTB. This research is important to be carried out to provide insight of communication science. In addition, this research can also be a government reference in composing effective communication in handling current and future outbreaks, especially related to communication noise. The method used in this research is descriptive-qualitative. Thus, the data presented is qualitative data. Quantitative data is only used by researchers to strengthen argumentation. Data sources in this research are various mass media, books, research reports that are relevant to this research topic. The researcher presents this research by describing the cases then analyzing the case with the relevant concepts and references. After that, researchers draw conclusions based on the results of the analysis based on observations and searches of various sources. This study found that there was communication noise in the Covid-19 handling process in NTB. The noise is physical, technical, semantic, and psychological noise. Physical noise affects people with disabilities because they receive less attention. Technical noise affected the process of aid distribution and outreach of the Covid-19 outbreak. Semantic noise causes the public insight into the concepts used by the government. Psychological noise makes people not follow the government's appeal.
\end{abstract}

Keyword: Noise; Communication; Covid-19

\begin{abstract}
ABSTRAK
Penelitian ini bertujuan untuk menggambarkan noise komunikasi yang terjadi dalam proses penanganan wabah Covid-19 di NTB. Penelitian ini penting dilakukan untuk memberikan wawasan dan menambah khasanah keilmuan komunikasi. Selain itu, penelitian ini juga dapat menjadi referensi pemerintah dalam menyusun komunikasi yang efektif dalam penanganan wabah saat ini maupun di masa depan terutama terkait noise komunikasi. Metode yang digunakan dalam penelitian ini adalah deskriptif-kualitatif. Dengan demikian, data yang disajikan merupakan data yang bersifat kualitatif. Data yang bersifat kuantitatif hanya digunakan peneliti untuk memperkuat argumentasi. Sumber data dalam penelitian ini adalah berbagai media massa, buku, laporan penelitian yang relevan dengan topik penelitian ini. Peneliti menyajikan penelitian ini dengan menggambarkan kasus-kasus kemudian menganalisis kasus tersebut dengan landasan konsep dan referensi yang relevan. Setelah itu, peneliti mengambil kesimpulan berdasarkan hasil analisis yang berdasarkan pada pengamatan dan penelusuran berbagai sumber. Penelitian ini menemukan bahwa terjadi noise komunikasi dalam proses penanganan Covid-19 di NTB. Noise tersebut adalah noise fisik, teknis, semantik, dan psikologis. Noise fisik berdampak pada orang-orang yang disabilitas karena mereka kurang mendapat perhatian. Noise teknis berdampak pada proses distribusi bantuan dan sosialisasi wabah Covid-19. Noise semantik menyebabkan wawasan masyarakat kurang terhadap konsep-konsep yang digunakan pemerintah. Noise psikologis membuat masyarakat tidak mengikuti himbauan pemerintah.
\end{abstract}

Kata kunci: Noise; Komunikasi; Covid-19 


\section{Pendahuluan}

Pemerintah Nusa Tenggara Barat (NTB) mengumumkan kasus pertama virus corona (Covid-19) pada 24 Maret 2020. Semenjak itu, kasus orang-orang yang terjangkit virus ini terus meningkat. Data pada tanggal 22 Juni 2020 yang dipublikasikan melalui website resmi pemerintah NTB dalam upaya penanganan Covid-19 menunjukkan bahwa ada 1.081 orang yang telah terpapar Covid-19 di NTB. Data tersebut juga menunjukkan rincian ada 45 orang yang meninggal akibat Covid-19, 744 orang sembuh, dan 292 orang masih dirawat di rumah sakit. Dalam rentang waktu sejak terjadinya kasus pertama hingga data terakhir, yakni pada Maret hingga Juni, berbagai masalah dalam penanganan Covid-19 terjadi salah satunya masalah dalam komunikasi ketika penanganan wabah sedang diupayakan. Ada berbagai Noise atau gangguan komunikasi yang terjadi antara pemerintah NTB dengan masyarakat saat proses penanganan Covid-19.

Lombokpost.jawapost.com pada tanggal 1 Mei 2020 memberitakan bahwa warga Bengkel, Kecamatan Labuapi, Lombok Barat pada tanggal 30 April 2020 ramai-ramai memprotes keputusan MUI bersama Pemerintah Kecamatan setempat terkait penundaan shalat Jumat di masjid dan menganjurkan untuk mengganti shalat jumat dengan shalat dzuhur di rumah masing-masing selama wabah Covid-19. Ratusan warga mendatangi kantor desa setempat untuk melayangkan protes. Kasus ini menjadi perbincangan di berbagai media online, bahkan menjadi perbincangan di tingkat nasional. Suparman, salah seorang anggota DPRD Lombok Barat dalam berita tersebut menilai perlu strategi sosialisasi yang baik kepada warga agar tidak menolak himbauan di tengah wabah.

Pada tanggal 25 Maret 2020, identitas dan foto pasien positif Covid pertama di NTB beredar luas melalui group-group aplikasi pesan instan (WA group). Indentitas dan foto pasien yang seharusnya menjadi rahasia dibagi dan diteruskan ke berbagai palatform media pesan instan dan media sosial. Jika merujuk pada protokol komunikasi publik terkait penanganan Covid-19, identitas dan lokasi pasien merupakan salah satu yang tidak boleh disampaikan kepada publik, akan tetapi yang terjadi justru sebaliknya. Identitas bahkan foto pasien pertama Covid-19 beredar luas kepada publik,

Detik.com memberitakan seorang pria berinisial SB ditangkap polisi pada tanggal 23 Maret 2020 karena menyebarkan berita bohong (hoax) terkait dengan Covid-19. Pria tersebut menyebarkan hoax melalui akun FB yang dimilikinya 8 Maret 2020. la menulis bahwa telah ada tiga korban yang terjangkit Covid-19 di Lombok. Pada saat berita itu tersebar, belum ada satupun informasi resmi yang mengatakan bahwa ada warga Lombok yang terpapar Covid19. Pria yang berasal dari Dusun Dasan Luah, Kabapaten Lombok Tengah itu mengaku menyebarkan informasi itu setelah mendapatkan pesan singkat dari nomor tidak dikenalnya yang mengatakan bahwa sudah ada tiga warga Lombok yang terjangkit Covid-19.

Kampung-kampung dan kelurahan di NTB mendadak ramai lockdown mandiri. Keputusan ini diambil berdasarkan inisiatif sendiri dari warga kampung dan kelurahan. 
Kompas.com memberitakan penutupan mandiri yang dilakukan kelurahan Karang Bedil, Mataram pada 1 April 2020. Lombokpsot.jawapost.com juga memberitakan sejumlah kampung di Mataram menutup diri pada 1 April 2020. Selain itu, media ini juga memberitakan sejumlah kampung di Lombok Tengah lockdown mandiri pada 30 Maret 2020.

Dari berbagai kasus yang telah peneliti jelaskan, peneliti bertanya, mengapa kasuskasus tersebut dapat terjadi? Mungkinkah ada noise dalam komunikasi yang diterapkan pemerintah dan pemangku kepentingan dalam menangani wabah Covid-19? Dalam tradisi ilmu komunikasi, dikenal istilah konsep noise atau gangguan dalam komunikasi. Noise sering kali menentukan sebuah peristiwa komunikasi berhasil atau tidak. West \& Turner (2008:12) menyebutkan bahwa dalam proses komunikasi, sering terjadi noise atau gangguan yang mempengaruhi kualitas komunikasi. Noise sendiri dapat berupa noise fisik, teknis, semantik, maupun psikologis.

Penelitian ini bertujuan untuk memberikan gambaran mengenai noise komunikasi yang terjadi selama penanganan Covid-19 di NTB. Peneliti berharap dengan mengidentifikasi dan memberikan gambaran noise yang muncul ketika upaya penanganan wabah di NTB dapat menjadi rujukan dan refleksi semua pihak yang terkait dalam menangani wabah Covid-19. Penelitian ini menjadi penting karena hasil analisis penelitian ini dapat menjadi panduan untuk mengantisipasi noise yang mungkin muncul ketika proses penanganan wabah di masa yang akan datang. Hasil penelitian ini dapat menjadi pertimbangan dalam Menyusun strategi praktis dalam menangani wabah di masa yang akan datang.

\section{Metode}

Penelitian ini merupakan penelitian deskriptif. Sedarmayanti \& Hidayat (2011) menekankan interpretasi yang tepat dalam penggunaan metode ini. Mereka menjelaskan metode deskriptif sebagai metode yang digunakan untuk menggambarkan fakta manusia, objek, kondisi, sistem pemikiran yang terjadi pada kondisi tetentu. Mulyana (2013) menyebut metode seperti ini sebagai metode "Hermaprodit" karena dengan menggunakan sifat data yang berbeda, maka penyebutanya akan berbeda juga. Sifat data dalam penelitian ini bersifat kualitatif, meskipun ada juga data-data berupa angka tetapi data tersebut hanya akan menjadi penguat argumentasi yang peneliti bangun. Dengan demikian, penelitian ini dapat disebut menggunakan metode deskriptif-kualitatif.

Dengan menentukan metode tersebut, peneliti membatasi penelitian ini hanya untuk mendeskripsikan data dan fenomean yang terjadi ketika wabah Covid-19 menyebar di NTB khususnya di bidang komunikasi. Fokus penelitian ini adalah untuk menggambarkan noise komunikasi yang terjadi selama penanganan Covid-19 di NTB. Data dalam penelitian ini bersumber dari berbagai litelatur baik beupa jurnal, laporan media massa, laporan penelitian, buku dan sumber dari internet yang relevan dengan penelitian ini. data-data yang disajikan dalam penelitian ini adalah upaya untuk membangun dan memperkuat argumentasi peneliti terkait noise komunikasi yang ada ketika penanganan Covid-19. Data dapat berkorelasi secara 
langsung maupun tidak, artinya dibutuhkan penelitian lanjutan untuk menguji korelasi antar variabel yang ada dalam proses ketika komunikasi berlangsung.

Penelitian ini disajikan pertama-tama dengan memberikan gambaran kasus yang terjadi di NTB ketika pemerintah NTB berusaha menangani wabah Covid-19. Setelah beberapa kasus disajikan, peneliti mengajukan pertanyaan kenapa peristiwa semacam itu dapat terjadi. Peneliti kemudian menyodorkan landasan konseptual yang dapat digunakan untuk menjelaskan fenomena atau peristiwa yang terjadi berdasarkan konsep noise dalam tradisi ilmu komunikasi. Selanjutnya, peneliti membahas dan menjelaskan peristiwa yang dengan konsep noise sebagai alat bedah. Kesimpulan peneliti lakukan kemudian ketika analisis dan bedah kasus dengan berbagai konsep dan sumber literatur yang relevan telah selesai.

\section{Hasil dan Pembahasan}

Noise fisik

Dalam upaya membantu masyarakat yang terdampak akibat wabah Covid-19, pada tanggal 17 April 2020 pemerintah NTB mendistribusikan Jaring Pengaman sosial (JPS) Gemilang. Akan tetapi, penyaluran bantuan JPS tersebut belum ramah terhadap penyandang disabilitas. Banyak penyandang disabilitas yang tidak mendapatkan bantuan dari pemerintah. Pemerintah NTB tidak hadir dan responsif terhadap keadaan ini. Organisasi non pemerintahan justru menaruh perhatian lebih kepada kelompok penyandang disabilitas ini. Radarlombok.co.id tidak memberitakan pemerintah NTB memberikan bantuan pada disabilitas melainkan Satgas NU NTB yang bergerak membantu mereka pada 8 Mei 2020.

Peneliti tidak menemukan informasi mengenai perhatian khusus pemerintah terhadap penyandang disabilitas hingga artikel ini dibuat. Hal ini menandakan kurangnya perhatian pemerintah terhadap kelompok masyarakat ini. Noise fisik dapat berupa keterbatasan fisik baik yang dialami komunikator dan komunikan. Penyandang disabilitas yang tidak memiliki kemampuan berkomunikasi dengan pemangku kebijakan di tengah wabah Covid-19 kesulitan untuk menyampaikan aspirasi mereka meskipun mereka adalah salah satu kelompok sosial yang rentan terjangkit virus Covid-19. Antaranews.com pada 12 Juni 2020 memberitakan bahwa kelompok disabilitas merupakan salah satu kelompok yang rentan terjangkit Covid-19. Kemampuan mereka terbatas saat melakukan aktivitas makan dan berkomunikasi. Hal itulah yang membuat mereka rentan. Berita tersebut juga menginformasikan bahwa 80,9 persen penyandang disabilitas terdampak secara ekonomi dan kesehatan.

Noise fisik berupa disabilitas menyebabkan kurangnya perhatian pemerintah NTB terhadap penyandang disabilitas meskipun jumlah penyandang disabilitas di NTB cukup tinggi. Globalfmlombok.com 2018 lalu memberitakan bahwa di NTB setidaknya ada sekitar 17.178 orang penyandang disabilitas. Jumlah ini tentu tidak bisa diabaikan di tengah pandemi. 
Noise fisik seperti disabilitas seharusnya mendapatkan perhatian khusus bagi pemerintah ketika ingin menangani wabah Covid-19 ini.

Kurangnya perhatian terhadap noise fisik dalam menangani Covid-19 juga tampak pada media yang digunakan dalam menyampaikan komunikasi kepada publik terkait dengan informasi Covid-19 di NTB. Berita televisi sangat jarang menambahkan bahasa isyarat bagi penyandang disabilitas pada tayangan yang berhubungan dengan Covid-19 di NTB. Inews TV memberitakan jumlah anak yang terpapar Covid-19 di Lombok Timur kian bertambah menyusul 10 orang anak positif Covid-19. Dalam berita yang disiarkan 27 Mei tersebut, tidak ada fasilitas bahasa isyarat yang ditampilkan. Beritasatu memberitakan tentang pintu masuk Kota Mataram yang semakin ketat akibat Covid-19 pada 4 April 2020. Berita tersebut juga tidak memfasilitasi penyandang disabilitas. Memang tidak semua siaran televisi tidak menyediakan bahasa isyarat untuk penyandang disabilitas. Akhir-akhir ini, sebagain besar televisi telah menampilkan bahasa yang dapat dipahami penyandang disabilitas. Hal ini patut menjadi perhatian pemerintah ke depan apabila terjadi wabah kembali. Saluran komunikasi yang tersedia harus memfasilitasi kebutuhan publik, terutama pubilk yang terpinggirkan seperti kelompok penyandang disabilitas. Noise fisik yang menyebabkan kurangnya perhatian pemerintah terhadap kelompok yang memiliki keterbatasn fisik dalam berkomunikasi untuk menyampaikan aspirasi dan apapun yang dirasakan di saat wabah harus menjadi perhatian dalam khusus dalam upaya merancang strategi komunikasi yang dilakukan pemerintah NTB ke depan.

\section{Noise Teknis}

Noise jenis ini terjadi ketika proses komunikasi antara komunikator dan komunikan mendapatkan kedala-kendala teknis sehingga pesan tidak tersampaikan dengan efektif. Noise teknis ini juga terjadi saat pemerintah NTB menangani Covid-19. Pada saat proses penyaluran bantuan bagi masyarakat yang terdampak Covid-19 di NTB, banyak data penerima bantuan yang tidak singkron. Kadinsos NTB justru melemparkan tanggung jawab kepada desa-desa penerima bantuan ketika data bermasalah. Hal ini mendapat kritik dari DPRD NTB seperti diberitakan diberitakan Koranntb.com pada 23 April 2020. Gangguan ini terjadi karena komunikasi yang dilakukan oleh pemerintah NTB hingga tingkat desa mengalami kendala teknis. Dalam proses pengumpulan data, tidak ada teknis yang jelas bagi pemerintah desa yang mengumpulkan data jika terjadi kesalahan data masyarakat yang berhak mendapatkan bantuan. Pemerintah Provinsi juga tidak melakukan pendampingan terkait pengumpulan data penerima bantuan. Hal ini menyebabkan kebingungan terhadap warga yang datanya bermasalah. Radarlombok.co.id juga memberitakan pada masalah yang sama terkait ketidaksingkronan data penerima JPS Gemilang pada 22 April 2020. Berita tersebut bahkan menginformasikan Kepala Desa Batulayar, Lombok Barat yang terkejut menerima data dari pemerintah provinsi karena banyak data yang tidak singkron. Masalah ini memperlihatkan kendala teknis komunikasi antara pemerintah provinsi hingga ke desa-desa yang tidak jelas. 
Noise teknis juga menyebabkan informasi mengenai Covid-19 di NTB tidak tersampaikan dengan baik. Salah satu kendala teknis dalam penanganan Covid-19 di NTB juga dipengaruhi kurangnya akses terhadap internet. Pemerintah NTB tidak mempertimbangkan dan mempriorotaskan masyarakat yang tidak mampu mengakses infromasi melalui Internet. Berdasarkan protokol komunikasi publik saat penanganan Covid-19 yang dipublikasikan di situs resmi pemerintah NTB, sosialisasi dan informasi terbaru tentang Covid-19 memang menggunakan berbagai kanal seperti internet, televisi, media online, cetak, radio, SMS gateaway, media sosial, jaringan sekolah, jaringan organisasi pemuda (Indonesia, 2020). Akan tetapi, informasi dominan terlihat pada kanal-kanal berbasis internet seperti media sosial, web resmi pemerintah NTB, media online. Sementara itu, jaringan sekolah dan jaringan kepemudaan tidak mendapatkan perhatian serius. Jaringan pemuda dan sekolah ini pada dasarnya dapat berperan penting dalam sosialisasi pada masyarakat yang tidak mampu atau kurang mengakses internet. Sementara itu, berdasarkan survey APJII pada 2018, pengguna internet di Indonesia masih didominasi oleh masyarakat Pulau Jawa. 95,5 juta pengguna internet terletak di Jawa. Sementara itu NTB yang digabungkan dengan Bali hanya memiliki 8,5 juta pengguna Internet atau hanya sekitar 5 persen(APJII, 2019). Meskipun penetrasi internet di NTB terbilang tinggi, tetapi hanya terjadi di kota-kota. Dengan demikian, pemerintah NTB perlu memperhatikan kanal-kanal offline untuk mencegah terjadinya noise teknis dalam sosialisasi terkait wabah.

\section{Noise Semantik}

Dalam tradisi ilmu bahasa, semantik dikenal sebagai salah satu cabang ilmu bahasa yang mempelajari arti dan makna. Verhaar (2010) mejelaskan semantik sebagai cabang ilmu bahasa yang meneliti tentang arti dan makna. Dia kemudian membagi semantik menjadi semantik gramatikal dan semantik leksikal. Semantik gramatikal menakankan perhatian pada makna berdasarkan pola sistematisnya sedangkan leksikal menkankan pada makna kata dalam upaya penyusunan kamus. Dalam tradisi komunikasi, noise semantik ini dapat diartikan sebagai kendala komunikasi karena bahasa yang digunakan oleh komunikator cenderung tidak dipahami dengan benar oleh penerima pesan karena kendala pengetahuan dan kemampuan bahasa penerima pesan baik secara gramatikal maupun leksikal tidak sama dengan komunikator.

Terjadi kebingungan di tengah masyarakat terkait istilah-istilah yang disampaikan oleh pemerintah melalui berbagai kanal sosialisasi. Kondisi ini disebabkan noise semantik terjadi dalam proses komunikasi antara petugas berwenang dengan masyarakat. Istilah-istilah seperti lockdown, rapid test, PCR, swab, ODP, PDP,OTG, social distancing, pysical distancing, hingga new normal yang sering digunakan pemerintah baik dalam sosialisasi bahaya Covid19 dan informasi rutin terkait perkembangan wabah ini tidak semuanya dapat dipahami dengan benar oleh masyarakat. Istilah-istilah tersebut terkesan sangat ilmiah dan tidak membumi. Istilah-istilah tersebut merupakan hal baru bagi masyarakat NTB dan tidak kemudian dapat langsung dimengerti. Inisiatif penutupan kampung-kampung secara mandiri 
disebabkan karena noise semantik karena istilah yang digunakan pemerintah dalam menangani wabah ini tidak diterima dengan benar oleh masyarakat. Istilah-istilah yang digunakan para pemangku kebijakan terkait penanganan Covid-19 di NTB dapat dipahami oleh masyarakat yang berpendidikan dan memiliki akses infromasi yang besar, tetapi belum tentu dapat dipahami oleh masyarakat yang kurang berpendidikan dan kekurangan akses infromasi.

\section{Noise Psikologis}

Schramm \& Robert (1971) menjelaskan konsep frame of referance yang diartikannya sebagai keseluruhan nilai-nilai, pengalaman, status ekonomi, bahkan kecenderungan politik seseorang. Perbedaan frame of referance antara komunikator dan penerima pesan maka semakin besar juga peluang noise komunikasi dapat terjadi dan menggoyahkan keefektifan komunikasi. Jurang frame of referance ini menjadi noise dalam upaya pemerintah menangani wabah Covid-19. Banyak masyarakat yang mengabaikan himbauan dan peringatan pemerintah mengenai Covid-19. Artinya, pengalaman, nilai-nilai, status ekonomi masyarakat membuat anjuran, himbauan pemerintah tidak dihiraukan. Penolakan warga bengkel menjadi bukti bahwa nilai-nilai agama yang mereka anut bertentangan dengan himbauan pemerintah mengenai shalat jumat. Ada noise psikologis berupa jurang frame of referance mengenai shalat jumat antara pemerintah dan warga. Pengalaman warga juga menjadi jurang dalam proses komunikasi yang terjadi. Tidak ada warga di dunia yang pernah mengalami terjangkit Covid-19 termasuk di NTB sebelum kasus pertama yang terkonfirmasi di China.

Noise psikologis ini juga terjadi karena tidak semua warga NTB dapat bekerja dari rumah. Ada jurang kesenjangan ekonomi dan kompleksitas mata pencaharian yang menyebabkan kendala komunikasi terjadi. Sebagian besar masyarakat NTB mencari nafkah dengan beraktifitas di luar rumah dan tidak dapat mencari nafkah jika berdiam diri di rumah. Berdasarkan data Bappeda NTB 2015, jumlah penduduk NTB yang bekerja pada sektor pertanian masih dominan. Sebanyak 903.139 warga NTB bekerja di sektor pertanian. Data ini berarti sekitar 43 persen warga NTB bekerja di sektor tersebut (Bappeda Prov. NTB, 2015). Data tersebut memberikan gambaran bahwa sebagian besar warga NTB adalah petani. Tidak mungkin masyarakat hanya bertani dari rumah. Mereka harus keluar rumah untuk mencari nafkah. Data tersebut belum termasuk masyarakat yang bekerja di sektor nonformal lainnya yang mengharuskan mereka keluar rumah. Artinya, noise komunikasi juga terjadi karena perbedaan status ekonomi.

Perbedaan frame of referance juga dapat disebabkan kesenjangan pengalaman dan akses pendidikan. Data BPS NTB menyebutkan bahwa angka partisipasi sekolah masyarakat NTB usia 16-18 tahun masih di angka 76,61 persen (E.T, 2017). Artinya, masih banyak warga NTB yang tidak sekolah pada usia produktif seperti usia 16-18 tahun. Meskipun data tersebut menujukkan peningkatan dibanding data tahun sebelumnya, jumlah usia produktif yang tidak berpendidikan di NTB tergolong banyak. Penggunaan istilah-istilah ilmiah dan akademis akan menyulitkan mereka yang berpendidikan rendah karena frame of referance mereka akan 
berbeda dengan yang berpendidikan tinggi. Penyebaran berita hoax dan data pasien pertama melalui media sosial dan pesan instan yang dilakukan warga juga menandakan kurangnya pendidikan mengenai media (literasi media) di tengah masyarakat. Kekurangan literasi media ini harus menjadi perhatian serius pemerintah ketika menghadapi wabah. Jangan sampai ada warga yang terjerat kasus hukum hanya karena tidak tahu dan tidak sadar bahwa Tindakan mereka dalam bermedia memiliki konsekuensi hukum. Di masa yang akan datang, sosialisasi dan peringatan mengenai kebijakan warga dalam bermedia dapat menjadi perhatian serius agar banjir informasi tidak menjerumuskan warga sebagai pelaku penyebar infromasi yang tidak benar.

\section{Simpulan}

Penelitian ini memberikan gambaran deskriptif bahwa terjadi noise komunikasi dalam proses penanganan Covid-19 di NTB. Noise tersebut adalah noise fisik, teknis, semantik, dan psikologis. Noise fisik berdampak pada orang-orang yang disabilitas karena mereka kurang mendapat perhatian. Noise teknis berdampak pada proses distribusi bantuan dan sosialisasi wabah Covid-19. Noise semantik menyebabkan wawasan masyarakat kurang terhadap konsep-konsep yang digunakan pemerintah dalam proses sosialisasi dan peringatan bahaya Covid-19. Noise psikologis membuat masyarakat tidak mengikuti himbauan pemerintah karena adanya jurang frame of referance yang cukup luas antara pemangku kebijakan dengan masyarakat awam. Jurang ini juga menyebabkan warga tidak selektif dan bijak dalam mengonsumsi dan menyebarkan informasi terkait Covid-19 di NTB.

\section{Daftar Pustaka}

Mulyana, Deddy (2013). Metode Penelitian Komunikasi: Contoh-contoh Penelitian Kualitatif dengan Pendekatan Praktis. Bandung: Remaja Rosdakarya

Sedarmayanti, \& Hidayat, S. (2011). Metodologi Penelitian. Bandung: Mandar Maju

Schramm, W., \& Roberts, D. F. (Eds.). (1971). The Process and Effects of Mass Communication (Rev. ed.). Urbana, IL: University of Illinois Press.

Verhaar (2010). Asas-asas Linguistik Umum. Yogyakarta: Gadjah Mada University Press

West, R., \& Turner, L. H. (2008). Pengantar Teori Komunikasi: Analisis dan Aplikasi. Jakarta: Salemba Humanika.

APJII. (2019). Pengguna Internet di Indonesia 2018 Bertambah 28 Juta \& nbsp; 1. https://databoks.katadata.co.id/datapublish

Bappeda Prov. NTB. (2015). Nusa Tenggara Barat Dalam Data Nusa.

E.T, W. (2017). Statistik Pendidikan Provinsi Nusa Tenggara Barat 2017. September 2016, 1-26.

Indonesia, R. (2020). Empat Pilar Komunikasi Publik Terkait Covid-19. 1.

Lombokpost.jawapost.com (2020, 1 Mei). Abaikan Larangan Berkumpul, Warga Bengkel Berkerumun

Minta Shalat Jumat Tetap Digelar. Diakses 30 Juni 2020, dari https://lombokpost.jawapos.com/giri-menang/01/05/2020/abaikan-larangan-berkumpulwarga-bengkel-berkerumun-minta-salat-jumat-tetap-digelar/

Detik.com. (2020, 23 Maret). Posting Broadcast Hoax Soal Positif Corona, Warga NTB ini Ditangkap. Diakses 30 Juni 2020, dari https://news.detik.com/berita/d-4949742/posting-broadcasthoax-soal-positif-corona-warga-ntb-ini-ditangkap 
Lombokpost.jawapost.com.(2020, 1 April). Antisipasi Korona, Sejumlah Lingkungan di Mataram Mulai "Lockdown Gubok". Diakses 30 Juni 2020, dari

https://lombokpost.jawapos.com/ntb/01/04/2020/antisipasi-korona-sejumlah-lingkungan-dimataram-mulai-lockdown-gubok/

Radarlombok.co.id. (2020, 8 Mei). Satgas NU NTB Peduli Bantu Disabilitas Terdampak Covid-19. Diakses 30 Juni 2020, dari https://radarlombok.co.id/satgas-nu-ntb-peduli-bantu-disabilitasterdampak-covid-19.html

Antaranews.com. (2020, 12 Juni). KPPPA: Anak Penyandang Disabilitas Rentan Terpapar Covid-19. Diakses 30 Juni dari https://www.antaranews.com/berita/1549540/kpppa-anak-penyandangdisabilitas-rentan-terpapar-covid-19

Globalfmlombok.com (2018, 9 Mei). Penyandang Disabilitas di NTB 17 Ribu Orang, Rata-Rata Masuk Kategori Miskin. Diakses $30 \quad$ Juni 2020 dari https://globalfmlombok.com/read/2018/05/09/penyandang-disabilitas-di-ntb-17-ribuorang-rata-rata-masuk-kategori-miskin.html

Koranntb.com. (2020, 23 April). Data Penerima JPS Gemilang Bermasalah, Dinsos NTB Dinilai Tak Becus. Diakses 3 Juli 2020, dari https://koranntb.com/2020/04/23/data-penerima-jpsgemilang-bermasalah-dinsos-ntb-dinilai-tak-becus/ 